\title{
Osama and The Entry of Al Qaeda to Southeast Asia in Historical Perspective: A Preliminary Note
}

\author{
Herdi Sahrasad ${ }^{1}$, Yanuardi Syukur ${ }^{2}$, Al Chaidar ${ }^{3}$, Dedy Tabrany ${ }^{4}$, Muhammad Ridwan $^{5}$ \\ ${ }^{1}$ Senior Lecturer at University of Paramadina, Jakarta \\ ${ }^{2}$ Lecturer in Social Anthropology of University of Khairun, Ternate and PhD candidate at Department of \\ Anthropology, University of Indonesia \\ ${ }^{3}$ Senior Lectrers at University of Malikussaleh, Aceh and PhD candidate at Department of Anthropology, \\ University of Indonesia \\ ${ }^{4}$ Police Science College (PTIK, Perguruan Tinggi Ilmu Kepolisian), Jakarta \\ ${ }^{5}$ State Islamic University of North Sumatera
}

sahrasad@yahoo.com

\begin{abstract}
Southeast Asia captivates Al Qaeda (Saudi Arabia/Middle East) to enter this region because Osama Bin Laden knows that Southeast Asia is the second priority of the US in fighting international terrorism. Southeast Asia is also referred to as "home" for terrorist groups or movements such as Jemaah Islamiah (JI), Abu Sayyaf and the Mujahideen Malaysia Group (KKM)) which were allegedly involved in the WTC case. Regardless of whether or not the involvement of "radical Islamic" groups was involved with "the September 11(9/11)'" case, which clearly has changed US relations with Southeast Asian countries. Meanwhile, the Islamic political movement, especially the political violence groups have increased and flourished in Indonesia since President Soeharto fell in 1998. Since the mid-1990s, a number of terrorist attacks have been planned in the Southeast Asia region, including attacks on church leaders (Pope), President Bill Clinton, and commercial aircraft. But these plans are not always successful, and all of the above factors, combined with the arrest of several people from the Al-Qaeda network operating in Southeast Asia, are seen as a strong enough driving factor to carry out the terrorism attacks in this region. Al Qaeda succeeded in building networks, supporters and cells through regional extremist movements affiliated with it. According to Asean intelligent report, they received financial and weapons amounted to US\$ hundred thousands from Al Qaeda on a scale that worried many people.
\end{abstract}

Keyword : Al Qaeda; Osama; terrorism; the US; Jamaah Islamiyah; Abu Sayyaf; Mujahdeen; Southeast Asia.

\section{Introduction}

Al Qaeda apparently chose the location of Afghanistan, beside of Middle East region, as the basis for its actions and networks because of geopolitical and geostrategic considerations. The "Country of mullahs", with strategic geopolitics, geographically borders on six other countries, namely. China, Pakistan, Iran and three former Soviet Union countries namely Turkmenistan, Tajikistan and Uzbekistan. The history of this country proves that the area includes commercial routes (Mir Zohair Husain, Global Islamic Politics, 2003,255). As a commercial route area, it certainly brings its own blessing and lures other countries to get it.

Ten years of conflict in this region (from 1979 to 1989), made Islamic extremists unite and gain training experience in war. The Communist government in Afghanistan won office in 1978, but did not succeed in maintaining control of its territory. In late 1979, the Soviet 
government sent its military unit to ensure that Afghanistan was safe under Moscow's influence. When the resistance movement of the Mujahideen took place, this war resulted in defeat for the Soviet forces (9/11 Commission Report: 72).

To accommodate the mujahidin and as a database, Bait al-Ansar and Maktab alKhidmat (the Service Bureau) were established by Abdullah Azzam and Osama bin Laden (Wright, 2007: 119). Later that day, the base turned into al-Qaeda, a social movement that was large and had implications for American counter-terrorism. Quoting Marc Sageman, Marlena Telvick said that "al-Qaeda has evolved from an operational organization into a larger social movement, and the implication for U.S. counterterror efforts "(al-Qaeda has grown from an operational organization to a larger social movement, and has implications for the efforts of the war on terror in the United States).

\section{The History of Al Qaeda}

According to Sageman (2004), al-Qaeda is really a social movement, "Al-Qaeda is really a social movement. People think of it as a hierarchical organization, like a military organization, but it was never that. It was always a network, like a peace movement, coalescing together for peace demonstration on a certain Sunday ... It has very fuzzy boundaries. Some people are part of it, some people are not. To think of it as having a fixed membership is an illusion. "

Sageman's research on four hundred terrorists who attacked the West and opposed the government in his country, said that Al-Qaeda had become a global jihadist movement - not bound by geopolitical and geopolitical boundaries. Telvick (2009) writes on the Public Broadcasting Service website, "He divided them into four large clusters: the old leadership of al-Qaeda; the Magreb Arabs (people from North Africa, Tunisia, Morocco and Algeria), including the second generation who grew up in Western Europe and whose parents came from those regions; the "core" Arabs (Egyptians, Saudis, Jordanians, Yemenis and Kuwaits); and the Southeast Asians (Indonesians).

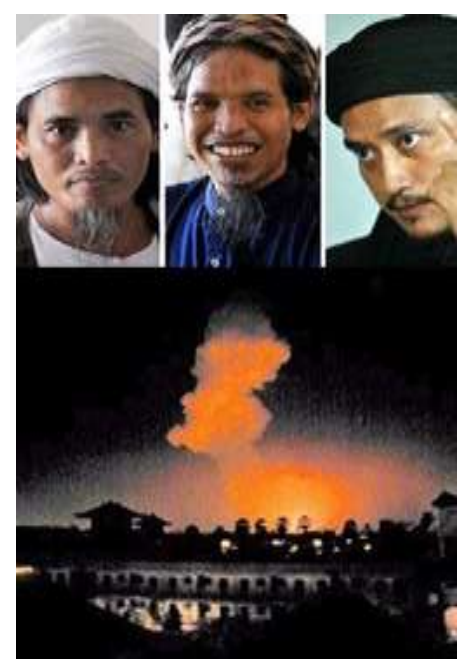

Figure 1. Three Bali Bombers (Amrozy, Mukhlas dan Imam Samudra), they are affiliated with Al Qaeda 
Sageman (2004) said that followers of The Global Jihad (Global Jihad) can be referred to as nodes (influential people) connected with links (network connectors). Each link has more relationships in a network called a hub (activity center). Al-Qaeda led by Osama bin Laden is a global jihadist movement which since 1998 issued a fatwa to kill Americans and Jews in every place and period.

Groups of people who are related to each other form also a cluster (cluster / group) of networks. Al-Qaeda's global network according to Williamson (2001) consists of four clusters made around nodes. Estimates about the number of nodes in the network are uncertain. Data released by the Central Intelligence Agency (CIA) estimated that around 110,000 people had been trained in al-Qaeda camps between 1989 and October 2001. Of this around 20,000 people had graduated between 1996 and 2001. In his February 2003 explanation before Congress, Director of the Federal Investigation Bureau (FBI) Robert Muller stated that hundreds of them were nodes related to al-Qaeda living and operating in the US alone (Hendropriyono, 2009: 199).

In 2000 under the supervision of al-Qaeda cadres from Spain named Omar Bandon and Jusuf Galan, the exercise was carried out. His second trip from Madrid to Poso via Bali, was guided by an al-Qaeda link named Parlindungan Siregar by managing funds that were originally only around 50 million US dollars before the 9/11 incident. Al-Qaeda's Finance Committee is led by Abu Fadel al-Makki and Abu Hamam as-Su'udi.

This commission has raised the power of money circulation for a network, which is unequaled in the world in similar organizations. By relying on an informal banking system called hawala, funds have been transferred through administrative boundaries and without the knowledge of national governments.

Al-Qaeda's Fatwa Committee was led collectively by Ayman al-Zawahiri, Fadel alMisiri, Abu Faraj al-Yamani, Abu Qatada, and Abu Hajar. The Fatwa Commission deals with the arguments of Islam that are used to compile political praxis. The Information Committee (media) led by Abu Mush'ab, nicknamed Abu Reuters (took the name of the Reuters news agency). The Information Commission relates to the Muslim environment for the purposes of coaching and raising as well as for publication to the world community.

The leaders and core members of al-Qaeda came from two militant Islamic factions from Egypt, namely al-Jihad led by Ayman al-Zawahiri and al-Jama'ah al-Islamiyah led by blind cleric Umar Abdurrahman. Al-Qaeda is said to have institutional relations, with no organizational ties with other institutions in more than 50 countries, including: Britain, Germany, Canada, the United States, Albania and Tanzania (Fachry, 2008: 56-58). This assumption can at least be seen from Robin Wright (2001) who mentions ".. Bin Laden established recruitment centers in over 50 countries to find volunteers to fight a Jihad ..." (Husain, 2003: 282). The volunteer recruitment centers could be the forerunner of cooperation with al-Qaeda because they previously had the same vision in the face of the Soviet invasion.

The Media Commission deals with the Muslim environment for the purposes of coaching and raising as well as for publication to the world community. In this inner axis, a command system (top down) applies to determine tasks, salaries, and positions or positions of personnel. According to Hendropriyono, the central staff structure that has the characteristics of such military organizations makes the organization's space to be more flexible to maneuver (move quickly). 
At the Military Commission, it has links with 4 (four) other clusters in various regions, including with organizations outside of al-Qaeda. The relationship was used to provide technical assistance, such as military training carried out by al-Qaeda for al-Jama'ah alIslamiyah (JI) in Poso, Central Sulawesi in 2000. The destruction of al-Jama'ah clandestine (underground or secret) organizations al-Islamiyah in Indonesia has blurred al-Qaeda's relations with other similar organizations. The obscurity was evident from the occurrence of a sharp grenade explosion made by Pindad on February 5, 2008 in a garage on Jalan Gatot Subroto, Jakarta. The second explosion that occurred on February 15, 2008 at the T-junction of Keboiwo, Denpasar, Bali, was not indicated at all with al-Qaeda.

The second cluster in the al-Qaeda movement is the position occupied by al-Qaeda members in Arab countries such as Saudi Arabia, Egypt, Yemen and Kuwait. In the book The Secret History of al-Qa'ida, Abdel Bari Atwan explained that since May 2003, al-Qaeda had opened a new branch in the Arabian Peninsula. Their struggle was to criticize the government of Saudi Arabia. At least two groups wanted change in Saudi Arabia, namely liberal opposition which is an education graduate from campuses in America and Europe, and jihadist groups who demand change with weapons. In addition to concentrating on domestic issues, al-Qaeda in Arabia also continues to target foreign targets (Fachry, 2008: 215) .

The third cluster is the Maghreb Arabs Cluster or known as the Bilad al-Magrib alIslami al-Qaeda Tandzim (al-Qaeda Organization in Maghrib Islamic Countries) or Al-Qaeda in the Islamic Maghreb (AQIM). The Maghrib region includes countries such as Morocco, Algeria, Libya and Tunisia. Initially this movement stood alone, but on September 13, 2006 a movement called Jama'a as-Salafiyyah Li ad-Dakwah wa al-Qital or in French was called "Groupe Salafiste la la Predication et le Combat" (GSPC) (Da'wah Salafi Movement and Jihad) under the leadership of Abu Musaab Abdul Wadud joined Al-Qaeda.

In the fourth cluster, namely the Southeast Asia region consisting of al-Jama'ah alIslamiyah (JI) and its cells in Indonesia, Singapore, the Philippines and Malaysia. According to Rohan Gunaratna in his book Inside al-Qaeda, "al-Qaeda has expanded its influence in Southeast Asia by utilizing the internet, infiltrating non-governmental Muslim organizations, sending extreme religious leaders to the region and training activists in Afghanistan".

\section{Discussion}

\subsection{Al-Qaeda in Southeast Asia}

The type of Al-Qaeda movement is not limited by territorial barriers, and the state. But to facilitate the analysis, in this study studied al-Qaeda who are active in the Southeast Asia region. In the book of Christian, Jewish, Islamic, Fundamentalist Terrorism, A.M. Hendropriyono (2009) writes that al-Qaeda has four clusters, namely the core cluster (inner axis) consisting of Osama bin Laden, Shura Assembly, and four commissions, Arab country clusters, Muslim country clusters in North Africa (Maghribi), and Southeast Asian clusters.

Southeast Asia is the place for the growth of the Al-Qaeda network in the Asian region. This fact also encourages the United States to increase its military presence in the Southeast Asia region both quantitatively and qualitatively. Increasing the United States Military in Southeast Asia by the United States in the context of combating international terrorism. With a number of criteria selected areas for Al-Qaeda expand its network, as well as with the character and orientation described earlier, reinforcing the view that Al-Qaeda has a large 
network in the Asian region, especially Southeast Asia, because the population is large. Because of this, Southeast Asia is the choice for Al-Qaeda to expand its network. According to the US there are several things that are the reason for Al-Qaeda to build networks in Southeast Asia (Abuza, 2002).

Firstly, Thousands of Muslim residents of Southeast Asia had and joined and fought along with the Mujiheddin forces in the 1980s. Secondly. Since the early 1980s also a wave of Southeast Asian people studying in the Islamic University and Middle Eastern Madrasas has increased dramatically. Thirdly, Frequent rebellion of rebellion of Muslim communities in Southeast Asia in secular governance (Saripudin HA, 2000). Radical Islam growing rapidly in this region along with changes in countries becoming more secular. Fourth, Southeast Asia is a "paradise" for the growth of terrorist networks. This is due to the weakness of police forces and security forces in Southeast Asia, so that terrorist groups easily operate.

In Southeast Asia, the group accused of being an extension of al-Qaeda is Jama'ah Islamiyah (JI), which was first led by Abdullah Sungkar. Although there is no organizational command relationship, movements in Southeast Asia, such as JI, have a common vision with al-Qaeda. Hijazi (2009), writes as follows: "... al-Qaeda as an organization, stands from the level of: active cells and sleeping cells spread in various countries of the world, Islamic groups accused of warring" to al-Qaeda and having a bond of thought and organizations with al-Qaeda ... although it is difficult to detect groups like this, but we can see some of these groups, such as: Qoidah al-Jihad fi Bilad al-Rafidain organization (Iraqi al-Qaeda Tandzim), Jama'ah Islamiyah (JI) in Indonesia (where one of its members is seen in the Bali BombingIincident)..."(p.85)

Researcher from the Center for the Study of Terrorism and Political Violence, Rohan Gunaratna said that al-Qaeda movement had expanded its influence in Southeast Asia by utilizing the internet, infiltrating Muslim non-government organizations, sending extreme religious leaders and training people in Afghanistan.

The Southeast Asia region is inhabited by no less than 210 million people who are Muslim. Even in the three ASEAN member countries, namely Indonesia, Malaysia and Brunei, the majority of the population are followers of Muhammad Saw. Under these conditions, many predict that Southeast Asia can become a fertile ground for the development of al-Qaeda and a safe hiding place for its members who are the target of the US government.

In Malaysia, 13 people from the Majelis Mujahidin (KMM) group were arrested by the government. According to the Center for Defense Information (CDI), between KMM and Jama'ah Islamiyah have cells or a kind of "slice" in Southeast Asia, and members of those who have trained in Afghanistan play a large part in al-Qaeda's expansion in Southeast Asia. One of them is Nurjaman Riduan Isamuddin, or known as Hambali who was once a leader in KMM (Website CDI, 2009).

Initially, the government only detained Yazid Supaat because he was suspected of having a special relationship with three suspects who were hijacking a plane that crashed into the Pentagon building in America in 2001. This suspicion arose because in January 2000 Supaat accepted the arrival of Khalid al-Mihdhar and Nawaf al-Hazmi in Kuala Mud and stay in an apartment that belongs to him. In September and October of that year, Supaat accepted Zacarias Moussaoui and stayed at his apartment. Supaat can only be caught after returning from Pakistan to Malaysia by land from Thailand. 
During his interrogation, a graduate chemist from one of the campuses in America revealed that he entered Afghanistan in October 2001 or shortly after the US began attacking Afghans. While there, he helped the Taliban Government by working in a health unit in the city of Kandahar. From Supaat's statement, Malaysian police arrested 12 members of the Malaysian Mujahidin Association (KMM) from which obtained a number of important documents relating to guerrilla warfare and studies of militant Islamic groups in the Philippines, Chechnya, Afghanistan and Indonesia (Nainggolan, et.al, p. 142 )

In the blog http://pintusyurgadipattani.blogspot.com, it appears that al-Qaeda Southeast Asia exists. In Malay, entitled "Khabar Gembira for Ummah!", It is written that based on the agreement of the Majlis Assy-Shura Al-Mujahidin who had consulted in Pattani Darussalam on 20 Rajab 1429, the Al-Qaeda Tandzim in the Southeast Asian region wanted to give good news to Muslims with three $p$.

First, the Al-Qaeda Southeast Asia Tandzim promises to remain submissive and obedient in full obedience to Allah and the Prophet in continuing jihad fi sabilillah. It was written in the blog, "We will always maintain our intentions in this Jihad and will strive diligently in upholding the sentences ' kalimatullah'" on this earth besides spurring a continuous and proactive effort in sparking a complete mix of the entire Mujahideen factions in Southeast Asia."

Secondly, Al-Qaeda's Southeast Asian Tandzim repeated the bai'at / pledge to remain obedient to Ulil Amri, the leader of the mujahidin such as Osama bin Laden and Ayman AlZawahiri. It was written in the blog, "We will continue to fight under the violet flag which he flies while where obedience to him does not violate obedience to Allah and the Messenger of Allah. We will occasionally not leave our baiah / pledge and we will not ask that he be canceled."

Third, the Southeast Asian al-Qaeda Tandzim will hold "Operasi Tawbah" which began in Muharam 1430. This operation will be a new surprise for the Thagut regime in Southeast Asia. Muslims are also asked to be prepared to start now to join in this operation. Tandzim also mentioned that he had made a new structure, namely: the highest leadership structure of Majlis as-Syuro al-Mujahidin. The Emir of the Shura Majlis named Abu Ukkasyah Al-A'rabi, Timbalan Amir named Imam Waqqas, General Awwal Abu Ubaidah and General Thani Abu Abdillah.

To help the Muslims who are captured by the government - which he calls the "government of thagut", then there are a number of things according to this group that need to be done, namely: First, attacking the Prison / place of the Mujahideen being held captive to release them if there is the ability to attack charming ransom than the police so that it can be used as an exchange for captive mujahideen; third, charming ransom than among foreign tourists, especially those from the United States, Thailand or their allies to be exchanged for Mujahideen who are captured in Indonesia; fourth, periodically initiating attacks on Indonesian police or soldiers so that they release the captured Mujahideen.

The statement on behalf of al-Qaeda's Tandzim in Southeast Asia was written in the name of Abu Ubaidah, "Muhajir and Mujahid Pattani Darussalam Accomplished the Southeast Asian Division of Al-Qaeda Regime".

The Detiknews news website (August 21, 2009) wrote that according to Al Chaidar, there was no al-Qaeda Southeast Asia. There is Jamaah Islamiyah (JI). In Indonesia, JI is named Tandzim Qoidatul Jihad. The Malay-language blog also uses the term Amir Majlis 
Syuro to refer to al-Qaeda's Southeast Asian leadership. Alchaidar said that Amir Majlis Syuro was not in Tadzim Qoidatul Jihad. Likewise with General Awwal (First General) and General Thani (Second General). It should be led by Mudabbir Syuro. Then direct members. Likewise, Pattani, a jihadist organization in Southern Thailand, is listed on the blog. According to $\mathrm{Al}$ Chaidar, the organization has long been inactive.

Who is actually a person who claims to be Southeast Asian Al Qaeda on the blog http://pintusyurgadipattani.blogspot.com is still mysterious. According to Sidney Jones, there was an allegation, the threater was a Malaysian who lived in Thailand. According to Jones, those who live in Thailand want to explain to outsiders what happened in Thailand. Since the site appeared, it was indeed interesting because there was an appeal from them so that people would come to Pattani for jihad.

In 2005, after the Bali bombing, Noordin M Top admitted as Al-Qaeda leader. The VOA-Islam website on August 21, 2009, wrote, "In the declaration of responsibility for the Bali II bombing in 2005, Noordin signed it in the name of" Qoidatul-Jihad Tandzim Leader for the Malay Archipelago, " a formulation that looked more like Malaysian than Indonesian. However, the "Malay Archipelago Cluster" refers to an area that includes at least Malaysia, Singapore, Brunei, the Philippines and Indonesia. In 2008, this site emerged claiming to be al-Qaeda Southeast Asia. 2009, the statement of Noordin Al-Qaeda Indonesia appears.

Sidney Jones (2009) questioned the site. On the International Crisis Group (ICG) website, he wrote, "If it's true that Noordin, in 2005, called himself al-Qaeda" for the Malay Archipelago Cluster ", why in the blog issued four years later, namely in http://mediaislambushro.blogspot.com, only mentioned" Al -Qo'idah-Indonesia?"

If the blog is true from Noordin's group, there are a number of possibilities. It could be that Noordin's space is limited, so it is impossible to reach outside Indonesia. Or there are other people who represent al-Qaeda in neighboring countries, so Noordin is forced to reduce his "sphere of influence".

Regarding the threat of al-Qaeda groups as stated in the blog above to the government to release prisoners, when they were not released, this group did not make any significant movements. In 2004, the threat emerged, but when no one was released, this threatening group could only silent According to Alchaidar, this is because the group only moves based on the fatwa of the ulema of the Taliban, Afghanistan and Iraq.

\subsection{Al-Qaeda in Indonesia}

In the International Herald Tribune news headline entitled "Southeast Asia Bars Help of US Troops" (12/14/2001), Hendropriyono said that al-Qaeda had collaborated with radical groups in Poso which were being hit by a dispute between Islamic and Christian groups. This dispute took several years and involved Muslims outside Poso, including those from Afghan jihad veterans.

The influx of al-Qaeda can be seen from the network of Jama'ah Islamiyah (the fourth cluster of al-Qaeda) operating in Poso. Operations carried out in this area are essentially a call for jihad to help oppressed Muslims in a place.

The Observer, Sunday 20 November 2005 writes as follows: "To jihadists across the archipelago and beyond, Poso's tensions were called to arms against the region's 200,000 Christians. By the summer of 2001, the best way to migrate, thousands of militants, from outlawed groups such as Laskar Jihad and Jemaah Islamiyah, have 
traveled with weapons, military training from Afghanistan and a mission to drive out the infidels. "

(Untuk pelaku jihad di seluruh nusantara dan luar, ketegangan Poso memanggil untuk memerangi 200.000 orang Kristen. Pada musim panas 2001, dengan sedikit usaha oleh pemerintah untuk menghentikan migrasi mereka, ribuan militan, terutama dari kelompokkelompok terlarang seperti Laskar Jihad (LJ) dan Jama'ah Islamiyah (JI), telah berkelana di sini dengan senjata, mengadakan pelatihan militer dari Afghanistan dan misi untuk mengusir kalangan kafir).

In responding to this fact, the Indonesian Government took a cautious stance, because there was no clear fact that al-Qaeda had been active in Indonesia. This caution was caused by Indonesia being a safe area, not a war zone like in Palestine or Afghanistan.

The Center for Defense Information (CDI) wrotes, "After months the government insisted that al-Qaeda did not operate in Indonesia, eventually supporting a public statement in December in which the intelligence services recognized the existence of an al-Qaeda training camp in Indonesia ... On In January, Foreign Minister Hassan Wirajuda denied having evidence that local Muslim organizations had links to international terrorist networks ... In February, Indonesia signed an agreement with Australia to fight international terrorism."

Until in 2002 there was a "Bali Bombing", Indonesian officials, such as Vice President Hamzah Haz, began to believe that signal, even Defense Minister Matori Abdul Jalil called the Bali Bombers carried out by al-Qaeda with the help of Indonesians. Meanwhile, former president Abdurrahman Wahid boldly named Abu Bakar Ba'asyir (Majelis Mujahidin), Habib Rizieq Shihab (Islamic Defenders Front) and Ja'far Umar Thalib (Laskar Jihad) as terrorists because they always used violence and carried everywhere homemade weapons. In the article "Al-Qaeda in Southeast Asia: Evidence and Response", it was explained that two Islamic leaders (Abu Bakar Ba'asyir and Ja'far Umar Thalib) had connections with alQaeda. Ba'asyir was allegedly the leader of Jama'ah Islamiyah (JI) as one of al-Qaeda's connections. JI was founded in 1993 as a fraction of Jama'ah Darul Islam, known as NII. JI is an organization or jama'ah by having leaders who are obeyed, members and organizational structure (Abas: 93-93).

Ba'asyir was born on August 17, 1938 in Jombang. He completed his education at Pondok Modern Gontor and the Da'wah School of the University of al-Irsyad, Solo, Central Java (1963). When students were activists of the Islamic Student Association (HMI), Pemuda al-Ershad, and chair of the Indonesian Islamic Youth Movement (GPII) in 1961. At the 2002 Mujahideen Congress, elected chairman of the Ahlul Halli wal Aqdi (AHWA) Majelis Mujahidin and later at the congress the second was re-elected as Amir of the Mujahideen for the period 2003-2008. In 1983, Ba'asyir and Abdullah Sungkar were arrested for allegedly inciting others to reject the single principle of Pancasila. In 1985, he traveled to Malaysia through Medan. According to the US Government, at that time in Malaysia Ba'asyir formed a radical Islamic movement, Jama'ah Islamiyah, which established relations with al-Qaeda (alAnsari, 2004: 66).

Whereas Talib, who founded Laskar Jihad (LJ) to help Muslims in Maluku, was known to have met Osama bin Laden in the 1980s, although he claimed to "to have rejected the offer of money from al-Qaeda" (refused funding from al -Qaeda). Laskar Jihad has a site that is accessed about the earth of jihad in Ambon. In addition, jihad information leaflets are also routinely distributed. 
In late July 2002, Indonesia announced that five members of al-Qaeda planned to attack the United States Embassy. Knowing that, President Bush sent a secret Delta Force team to Jakarta to improve security, but the incident did not occur (Website CDI, accessed on December 11, 2009). What was feared happened because the five members of al-Qaeda were not involved. However, three months later (October), a new bomb exploded in Bali on October

2002. In his article entitled "Who are the terrorists in Indonesia?", Sidney Jones (2009), saw the incident with three theories summarized below: First, the American embassy issued a warning to its citizens to avoid public places in Indonesia twelve hours before the explosion. The CIA chose a place frequented by Americans and supplied materials for bombs. From that incident, al-Qaeda and radical Islam became accused. This was done as an effort to win support for the war against Iraq, and offered to help with the investigation as a way to infiltrate American forces into Indonesia so that America could finally build a new footing in Southeast Asia.

The second theory, according to Jones, is common among Indonesians living in conflict areas. This theory shows that the Indonesian National Army (TNI) was the culprit. The TNI has tried since the fall of Suharto to reaffirm his role in provoking the government with conflict and then coming to enforce order. Proponents of this theory state that in reality the army supported the formation of Laskar Jihad (LJ), or the involvement of special forces soldiers in the death of Papuan independence leader, Theys Eluay. The struggle between the army and the police to control internal security has become increasingly bitter and violent in the past year, and on the scale of the Bali explosion can support the army. Aceh and Papua activists believe that a new anti-terror policy will be used by this group.

The third theory is "al-Qaeda theory" (al-Qaeda's theory), but has few supporters. This theory sees that relentless US pressure on the Indonesian government to act against Indonesian citizens associated with the Jama'ah Islamiyah illegal network has convinced many Indonesians that their own security bodies are forced to accept the US version of events. Information from Umar al-Faruq - the man who was arrested in West Java in June 2002 - published in Time magazine, proves that there was a plan by the al-Qaeda group to kill President Megawati (The Observer, 27/10/2002).

The day after the Bali Bombing (October 13, 2002), according to Soeripto, Australian Prime Minister John Howard accused al-Qaeda behind the attack. US President George Walker Bush, on the same day as Howard's statement, via CNN broadcast said that the bombing pattern behind Balik was similar to the pattern carried out by Middle Eastern terrorists. From Israel, the Zionist State's Institute for Counter-Terrorism (ICT), that day also boldly addressed Islamic militants associated with al-Qaeda as the perpetrators of the attack.

Indonesia as a majority Muslim country has become a soft terrorist target. Jonathan Weisman wrote a report in USA Today that the Pentagon had scheduled a plan to send troops to Indonesia. The target was to silence Islamic radical groups that were suspected to be the arms of the al-Qaeda network and were considered threatening American interests in SoutheastAsia.

Citing US intelligence sources, USA Today has written dozens of al-Qaeda operators now roaming freely in the region of 17,000 islands, inhabited by hundreds of millions of Muslims and has a 34,000-mile coastline. Information about the existence of al-Qaeda in Indonesia 
was obtained from the results of monitoring activities in and out of Middle Eastern waters, as well as monitoring activities around the borders of Pakistan and Iran.

President Bush once mentioned Iraq, Yemen and Indonesia as targets for the next operation after Afghanistan. When the Financial Review reporter on March 15, 2002, asked him if Indonesia was hesitant - like Somalia - in the face of terrorism, what would America do? Bush replied, "We will definitely take action to protect the safety of citizens and US national interests. We will not hesitate to do it."

Dozens of Islamic fighters, mostly from the Middle East, have openly worked on local Islamic groups in several Indonesian islands. The most prominent is their work in helping Muslims in the Islamic-Christian conflict in Maluku. Abu Abdul Aziz, one of Osama bin Laden's beliefs in July 2001, had come to Ambon and approached Laskar Jihad, but Ja'far Umar Thalib refused on the grounds that he had no experience in arranging foreign visas. Laskar Jihad, is a movement involved in the conflict. The Warriors Commander, Ja'far Umar Thalib, was said to have trained with the Osama bin Laden group in Afghanistan. Al-Chaidar also admitted that "Osama people had been to Indonesia" (Buana, ed., 2001: 179).

Junaedi (2003) wrote that other radical Islamic groups that received attention by intelligence were the Islamic Defenders Front (FPI), the Islamic Youth Movement (GPI) and the Majelis Mujahidin. FPI and GPI have no connection with al-Qaeda. But it cannot be denied that this movement has recruited jihadist forces and is determined to help the Taliban and al-Qaeda in

According to Muhammad Fachry and Fauzan al-Ansari, al-Qaeda in Southeast Asia and Indonesia (structurally-formal) did not exist. Fachry acknowledged, the terrorists had a kinship relationship from marriage, a kind of kinship terrorist. The Southeast Asian group needs to send a kind of al-Qaeda establishment request, after being approved at the central level (the first cluster), then proceeding with the declaration. During this time according to him, there has been no official declaration from al-Qaeda Southeast Asia, and the official statement from al-Qaeda Osama bin Laden. The Declaration was a necessity, as was the case when the Islamic front in 1998 was formed, and the declaration of the merger of the Daafi Da'wah and Jihad Movement in the North African region (Algeria, Morocco and Libya) with al-Qaeda. According to al-Ansari, the al-Qaeda network in Southeast Asia and Indonesia is not in the form of an organization, but a personal network (interview, 06 December 2009, Fachry,2008:219).

Until now, there is no clarity in the al-Qaeda network in Southeast Asia. However, it is coordinatively possible that this movement (in the form of an underground organization clandestine) shows an indication in that direction. This can be seen from the terrorists who came from War alumni in Afghanistan, and attacks on Western civilians. This is relevant to Bin Laden's fatwa on the killing of Americans and Jews (civilian and military) wherever they are.

In this context, Sydney Jones (2009), writes: "It is never clear whether al-Qaeda Southeast Asia really exists. Even if there is, is there a relationship with Noordin. One possibility is that the Abu Ubaidah group borrowed al-Qaeda's name simply because it agreed with Osama's ideology, not because they were under the authority of the central al-Qaeda leader ... Although it could happen, there is no single point of evidence that Noordin and some Asians The other Southeast has been pledged as a member of al-Qaeda." 
One question that is temporarily sought is the identity of an Algerian, named Jakfar, who at the end of 2007 and early 2008 was in Jakarta. It was Jakfar who in early 2008 accompanied two JI officials to Kuala Lumpur and gave plane tickets to Damascus, Syria, to them and two fake passports. A day later, JI people were arrested and Jakfar disappeared. Suspicion is circulating that Jakfar is a North African affiliate of AQIM (al-Qaeda in the Islamic Maghreb), but there is no clarity about that.

\section{Conclusion}

In Indonesia, the existence of this movement can be seen from the personal network of its members who have a vision of Osama bin Laden's global jihad. This personal network, because it does not manifest itself formally, is in the form of a Formless Organization (OTB). Structurally not visible, but the actions are real. That means, this organization exists and is underground (clandestine). This is a choice of movement, one of which is for the security of itsactions.

Organizationally, on behalf of al-Qaeda (with the name "al-Qaeda) still needs to be traced back. As for the recognition from the internet which states that its movement as tanzim al-Qaeda needs further investigation. In al-Qaeda, the recognition of the existence of alQaeda institutions needs to be realized by declaration, and there is an official statement from al-Qaeda center led by Osama bin Laden. Whereas the statement on the internet is still unilateral, and there is no official data statement from al-Qaeda center (in the al-Qaeda center itself this movement is still confidential). To obtain data from official terrorist sources, including not easy, it takes a long time because the form of the organization is confidential or a Formless Organization.

Al-Qaeda is referred to as a clandestine (underground) organization or formless organization (Organisasi Tanpa Bentuk - OTB), because this movement does not have a structure known to the public. In an organization, there are four things that must be owned in it, namely: having clear goals, having a leader, having a structure, and having followers (subordinates). Al-Qaeda includes the clandestine movement because its structure is not clearly visible. Therefore, the influence that al-Qaeda gives to the terrorist movement in Indonesia lies with people and actions. Those who were recruited by al-Qaeda then after going through a series of doctrines, finally carried out activities similar to al-Qaeda's vision. This can be seen in the activities of the Bali Bombing, Brass Bombing, Marriot and RitzCarlton in Indonesia and several bombing in Manila and Mindanao, Southern Phillipines.

After the 9/11 WTC bombing, Al Qaeda took an interest in operating in Southeast Asia, the place for the growth of the Al-Qaeda network in the Asian region. At the beginning of this century, conflicts in Ambon and Poso and southern Mindanao motivated Al Qaeda to strengthen its network and operations. With the large Muslim population, apart of them the discontented elements, Southeast Asia has encouraged Al-Qaeda to expand its network and operations in the region. With all of the above factors, combined with the arrest of several people from the Al-Qaeda network operating in Southeast Asia, are seen as a strong enough driving factor to carry out the terrorism attacks in this region. For the time being, Al Qaeda succeeded in building networks, supporters and cells through regional extremist movements affiliated with it. In such a manner as described above, in the past, Al Qaeda was eventually present in Southeast Asia. 


\section{References}

Abas, Nasir. Memberantas Terorisme, Memburu Noordin M. Top. Jakarta: Grafindo, 2009

Abas, Nasir. Membongkar Jamaah Islamiyah: Pengakuan Mantan Anggota JI. Jakarta: Grafindo, 2007

Al-Anshari, Fauzan. Ustad Abu Melawan Imperium Amerika. Jakarta: Penerbit Teras, 2004

As-Suri, Abu Mush'ab. Perjalanan Gerakan Jihad (1930-2002): Sejarah, Eksperimen, dan Evaluasi (Da'wah al-Muqawwamah al-Islamiyyah al-'Alamiyyah Bab: Hashad asShahwah al-Islamiyyah wa at-Tayar al-Jihadi-terj. Agus Suwandi). Solo: Jazera, 2009

Azra, Azyumardi. Konflik Baru Antar Peradaban: Globalisasi, Radikalisme \& Pluralitas. Jakarta: PT. RajaGrafindo Persada, 2002

Al-Zawahiri, Ayman.Dari Rahim Ikhwanul Muslimin ke Pangkuan al-Qaida.Klaten: Kafayeh, 2008

Buana, Zia Permata (ed.). Hanya Satu Kata: Jihad! Melacak Jejak Osama bin Laden dan Jaringannya. Jakarta: Penerbit Harakah, 2001

Chomsky, Noam. Power and Terror: Perbincangan Pasca Tragedi WTC 11 September 2001, Menguak Terorisme Amerika Serikat di Dunia (Power and Terror: Post 9/11 Talks and Interviews - terj. Syafruddin Hasani). Yogyakarta: Ikon Teralitera, 2003

Conboy, Ken. Intel II: Medan Tempur Kedua (The Second Front: Inside Asia's Most Dangerous Terrorist Network-terj. Syahrini Dyah N). Jakarta: Pustaka Primatama, 2008

Darraz, Isham. Sosok Mujahid Sejati: Usamah bin Muhammad 'Awad bin Ladin (Usamah bin Ladin Yarwi Ma'arik Ma'sadah al-Anshar al-'Arab bi Afghanistan-terj. Alimin). Jakarta: Cendekia Sentra Muslim, 2001

Daulay, Richard. Amerika VS Irak: Bahaya Politisasi Agama. Jakarta: Penerbit Libri, 2009

Dreyfuss, Robert. Devil's Game: Orchestra Iblis, 60 tahun Perselingkuhan AmerikaReligious Extremist (Devil's Game: How the United States Helped Unleash Fundamentalist Islam - terj. Asyhabudin \& Team SR-Ins Publishing). Yogyakarta: SRIns Publishing, 2007

Edwards, Beverley Milton \& Hinchcliffe, Peter. Conflicts in the Middle East Since 1945. London \& New York: Routledge, 2004

Esposito, John L. Saatnya Muslim Bicara. Bandung: Mizan, 2008

Esposito, John L. Unholy War: Teror Atas Nama Islam (Unholy War: Terror in the Name of Islam - terj. Syafruddin Hasani). Yogyakarta: Ikon Teralitera, 2003

Fachry, M. In the Heart of al-Qaeda: Biografi Usamah bin Ladin \& Organisasi Jihad alQaeda. Jakarta: Ar-Rahmah Media, 2008

Gurr, Ted Robert. Why Men Rebel. New Jersey: Princeton University Press, 1971

Halliday, Fred. The Middle East in International Relations: Power, Politics and Ideology. UK: Cambridge University Press, 2005

Hamka.Sejarah Umat Islam, cet. 5. Singapura: Pustaka Nasional, 2005

Hendropriyono, A.M. Terorisme Fundamentalis Kristen, Yahudi, Islam. Jakarta: Penerbit Kompas, 2009

Hijazi, Akram. Salafi Jihadi \& Masa Depan Jihad di Palestina (Rihlah fi Shamimi Aqli asSalafiyah al-Jihadiyah—terj.Abas Sungkar \& Mush'ab). Klaten: Kafayeh Cipta Media, 2009 
Hiro, Dilip. War Without End: the Rise of Islamist Terrorism and Global Response. London \& New York: Routledge, 2002

Hornby, A.S, Gatenby, E.V, Wakefield, H. The Advanced Learner's Dictionary of Current English. London: Oxford University Press

Huntington, Samuel, et.al. Amerika dan Dunia: Memperdebatkan Bentuk Baru Politik Internasional (America and the World: Debating the New Shape of International Politics - terj. Yusi A. Pareanom \& A. Zaim Rofiqi). Jakarta: Yayasan Obor Indonesia, 2005

Huntington, Samuel. Benturan Antar Peradaban dan Masa Depan Politik Dunia (The Clash of Civilizations and the Remaking og World Order-terj. M Sadat Ismail). Yogyakarta: Qalam, 2007

Hussein, Fuad. Generasi Kedua al-Qaidah: Apa dan Siapa Zarqawi (az-Zarqawi: al-Jail alTsani li al-Qa'idah—terj. Ahmad Syakirin). Solo: Jazera, 2008

Humphrey Wangke, Strategi ASEAN Menghadapi Terorisme, dalam Poltak Partogi Nainggolan, Terorisme dan Tata Dunia Baru, Jakarta: Sekjen DPR, 2002

Jones, Sydney “Noordin's Dangerous Liaiasons," Tempo, August 9, 2009.

Juergensmeyer, Mark. Teror Atas Nama Tuhan: Kebangkitan Global Kekerasan Agama (Terror in the Mind of God: The Global Rise of Religious Violence-terj. M. Sadat Ismail). Nizam Press \& Anima Publishing, 2002

Junaedi, Dedi. Konspirasi di Balik Bom Bali: Skenario Membungkam Gerakan Islam. Jakarta: Bina Wawasan Press, 2003

Keith F. Punch. Introduction to Social Research: Quantitative and Qualitative Approaches. London, California, New Delhi: Sage Publications, 2005, $2^{\text {nd }}$ edition

Laden, Usamah bin.Nasehat dan Wasiat Kepada Umat Islam dari Syaikh Mujahid Usamah bin Laden. Solo: Granada Mediatama, 2004

Lewis, Bernard. The Crisis of Islam: Islam dalam Krisis Antara Perang Suci dan Teror Kotor. Surabaya: Jawa Pos Press, 2004

Luthfi, Musthafa. Melenyapkan Hantu Terorisme dari Dakwah Kontemporer. Jakarta: Pustaka Al-Kautsar, 2008

Mahajan, Rahul. Melawan Negara Teroris (Full Spectrum Dominance: U.S. Power in Iraq and Beyond - terj. Anom). Jakarta: Penerbit Mizan, 2005

McClellan, Scott. Kebohongan di Gedung Putih (Inside the Bush White House and Washington's Culture of Deception - terj. Hendro Prasetyo). Jakarta: Gramedia, 2009

Mearsheimer, John \& Walt, Sthepen.The Israel Lobby Menguak Kuasa Yahudi di Amerika (The Israel Lobby and US Foreign Policy_Raja Ari Hidayat). Jakarta: Kalam Indonesia, 2007

Moleong, Lexy J. Metodologi Penelitian Kualitatif. Bandung: Remaja Rosdakarya, 2005

Nainggolan, Poltak Partogi, (ed.). Terorisme dan Tata Dunia Baru. Jakarta: Tim Peneliti Hubungan Internasional P31 DPR-RI, 2002

Olive, David. Mau Kemana Obama?(An American Story: The Speeches of Barack Obamaterj.Hari Ambari dan Dewi Anggraeni) Jakarta: Zahra, 2008

Permata, Ahmad Norma (ed.). Agama dan Terorisme. Surakarta: Muhammadiyah University Press, 2006

Petras, James. The Power of Israel in USA. Jakarta: Zahra, 2008 
Pickthall, Mohammed Marmaduke. TheMeaning of the Glorious Koran. New York: The American Library, 1956

Qutb, Sayyid.Masa Depan di Tangan Islam (al-Mustaqbal lihadza al-Din). Riyadh: International Islamic Publishing House, 1991

Qutb, Sayyid. Petunjuk Jalan (Ma'alim fi at-Thariq-terj.A. Rahman Zainuddin). Jakarta: Media Dakwah, 2001

Rohan Gunaratna, Terrorism In Southeast Asia: Threat And Response, Center For Eurasian Policy Occasional Research Paper Series Ii (Islamism In Southeast Asia), No. 1, (Singapore : Hudson Institute, 2006

Robin Wright, Sacred Rage: The Wrath of Militant Islam, Touchstone; Updated, Subsequent edition (December 4, 2001)

Rahmat, M. Imdadun. Arus Baru Islam Radikal: Transmisi Revivalisme Islam Timur Tengah ke Indonesia. Jakarta: Penerbit Erlangga, 2005

Sabirin, Tabrani (ed.).Menggugat Terorisme. Jakarta: CV. Karsa Rezeki, 2002.

Samudra, Imam. Aku Melawan Teroris! Solo: Jazera, 2004

Sihbudi, Riza. Menyandera Timur Tengah. Jakarta: Mizan, 2007

Saikal, Amin. Islam \& Barat: Konflik atau Kerjasama (Islam and West: Conflict or Cooperation-terj. Abdul Halim Mahally \& Tubagus Mundzir). Jakarta: Sanabil Pustaka, 2006

Sageman, Marc, Understanding Terror Networks, Unabridged, April 16, 2004.

Santoso, Thomas. Teori-Teori Kekerasan. Jakarta: Penerbit Ghalia Indonesia, 2002

Salam, Moch Faisal. Motivasi Tindakan Terorisme. Bandung: Penerbit Mandar Maju, 2005

Suradji, Adjie. Terorisme. Jakarta: Pustaka Sinar Harapan, 2005

Sunarko, A Dwi Hendro. Ideologi Teroris Indonesia. Jakarta: Pensil-324, 2006

Tharsyah, Adnan. Islam Kok Dilawan!Solo: Jazera, 2008

Whittaker, David J, (ed.). The Terrorism Reader: Second Edition. London \& New York: Routledge, 2003

Widodo.Cerdik Menyusun Proposal Penelitian: Skripsi, Tesis dan Disertasi. Jakarta: Magna Script, 2004

Wright, Lawrence. The Looming Tower: Al-Qaeda and the Road to 9/11. New York: Vintage Books, 2007

Zainuddin, AR. Pemikiran Politik Islam: Islam, Timur Tengah dan Benturan Peradaban. Jakarta: Pensil-324, 2004

Zed, Mestika. Metode Penelitian Kepustakaan. Jakarta: Yayasan Obor Indonesia, 2008

Zohair Husain, Mir, Global Islamic Politics, University of South Alabama, 2003

\section{Magazines, E-Book, and Website}

Sabili Magazines

Jihadmagz Magazines, $3^{\text {rd }}$ Edition 2008

9/11 Commission Report (Laporan Komisi 9/11)

http://www.deplu.go.id (Departemen Luar Negeri RI)

http://www.fbi.gov (Federal Bureau of Investigation)

http://www.cfr.org (Council on Foreign Relations)

http://pbs.com (Public Broadcasting Service)

http://cdi.com (Center for Defence Information)

DOI : https://doi.org/10.33258/birci.v2i2.232 
http://detik.com (Detik)

http://pintusyurgadipattani.blogspot.com (Khattab Media Publication)

http://voa-islam.com (VOA Islam)

http://crisisgroup.org (International Crisis Group)

http://observer.com (Observer)

http://surya.co.id (Surya)

http://kabarnusantara.com (Kabar Nusantara)

http://dinasulaeman.wordpress.com (Dina Y. Sulaeman)

\section{Interview}

Fauzan al-Anshari

Lutfi A Tamimi

Muhammad Fachry 